\title{
The Political Functions of Yoweri Museveni’s Bible Hermeneutics in Uganda
}

\author{
Robert Kuloba Wabyanga, PhD \\ Department of Religious Studies, Kyambogo University, Uganda.
}

\begin{abstract}
Yoweri Museveni, the President of Uganda"s rendition of Bible texts and stories in his political speeches has become part of his political trademark. Many of his speeches are thus reworked in coherent didactic rhetorical statements in an effort to galvanize his political base and agenda which is focused on the ideals of Pan Africanism, nationalism, democracy and socio-economic transformation in Uganda and East Africa as a region. Second, his book "The Mustard Seed" is reminiscent of the New Testament biblical parable like in Matthew 13:31-32. This article attempts to examine how these ideological nuances are involved in Museveni"s parabolic and proverbial rendition of Bible texts, and how they are practically manifested in Uganda. The article is a critical analysis and description of the Museveni biblical sayings in correspondence with his political agenda and ideology.
\end{abstract}

\section{BACKGROUND INFORMATION}

Yoweri Museveni's rhetorical rendition of the Bible texts and stories in his political speeches has become part of his political trademarks. Certainly, there are other things Museveni shall be remembered for in modern African history. For example, his recent attitude and criticisms against the International Criminal Court (ICC), his conservative attitude to gay rights, his role in East and Central African regional politics and the numerous domestic socio-economic and political reforms in Uganda. Many of Museveni's speeches are awash with biblical stories and texts; stories and texts that are reworked in a coherent didactic rhetorical statements to galvanize the president's speeches and addresses. This interminable practice by the political figure begs for a scholarly attention alongside other trends of contextual Bible studies in Sub-Saharan Africa. Museveni does not use the Bible in the conventional sense of devotion and inspiration. He is also not commonly associated with any Christian group, and also known for keeping a critical distance from Christian Churches.

Museveni's repeated verbalization of the Bible texts in his speeches is deeper than humorous rhetoric that is associated with popular politicians. It partly accentuates the centrality of the Bible in the African socio-cultural contexts, but also reveals a new twist in relation to the role of the Bible in African politics. Museveni often synthesizes the Bible texts and stories in rhetorical and literary didactic statements that constitute his political speeches. Museveni's Bible rendition seems hermeneutical in outlook, but a hermeneutics with its idiosyncrasy from what we know as African Biblical Hermeneutics that is commonly associated with African theologians. To use Gifford's words, African Biblical Hermeneutics focuses on "how issues raised in the Bible can be interpreted and addressed within the social, cultural and religious context of Africa," and creates "a dialogue between the text and the African context through the process of appropriation." The Bible is a world in itself. However, it shares socio-economic and cultural affinities with the African world context, which makes it a very important tool of interpreting and dealing with Africa's issues. In fact as Mbiti would put it, "Africans hear and see a confirmation of their own cultural, social and religious life" in the Bible. Museveni's Hermeneutics is unique and serves a political ideological purpose. Whereas African Biblical Hermeneutics forges the continuity between the African socio-cultural and religious antecedents and the Bible, This continuity lacks in Museveni's hermeneutics, which can only be understood as parabolic or proverbial appropriations of the Bible in the politics. In line with this view, Mr. Museveni has written a book, whose title- "The Mustard Seed" reminds us of the biblical parable of the Mustard Seed (Matthew 13:31-35, Mark 4:30-34, Luke 13:18- 21). In some cases, he uses either African sayings/proverbs or combines both African saying and the Bible verse. 
In his book, Museveni intimates that his participation in armed struggles was a sacrifice to reverse Uganda's "pitiable situation," He states that he was preparing the ground for "the mustard seed" of freedom and democracy to be sown in Uganda." Museveni portrays himself as the risk bearer, indeed the godly messianic figure-reminiscent of the biblical Jesus to deliver Uganda from bad regimes. Jesus told the parable of the Mustard Seed' when he was teaching about the Kingdom of God: a small seed that germinated and became a big tree upon which all birds of the air perched. In planting the Mustard, Museveni claims to have heralded the benefits of democracy and freedom to the effects similar to the biblical Mustard Tree: All birds of the air perched. However, who are these birds in the Ugandan context? Certainly it should be all the people of Uganda. We shall make a critical review of the political situation in Uganda later in this article. Museveni also states that his political agenda that is based on broad ideals of pan-africanism, nationalism, social economic transformation and democracy.

\section{The Bible in Uganda and other Contemporary Political Contexts}

Uganda is a predominantly Christian Country. $85.1 \%$ of the total population of Ugandans is Christians. Christianity was introduced in Uganda by the Church Missionary Society (CMS) and White Fathers in late 1870s. The missionary enterprise in East Africa came with the Bible, which was the hallmark of the Christian faith and Western civilization. The Bible was initially in English but later translated into various local languages like Luganda and Kiswahili. This widened the scope of readership as many Africans read the Bible as word and voice of God in their dialects. The centrality of the Bible in African socio-cultural contexts has received a commendable level of scholarship, thanks to scholars like Gerald West, David Adomo, Justin Ukpong, John Mbiti, and many others who have produced a flurry of scholarly writings. The Bible serves various purposes. It has become an enduring weapon "of power more like the gun," as Gerald West would like to call it. The Bible is a book of devotion, a rule of life whose authority is unquestionable. In 2008, the Christian community allover East Africa was outraged when Muamar Gadhafi, then Libyan President referred to the Bible as a forgery. A statement issued by Rev. Canon Aaron Mwesigye, the provincial secretary of the Anglican Church of Uganda, read in part that: "Many scholars have proven the accuracy of the Bible, and God Himself has shown it to be true."

Uganda is a context with a history of bloodshed and death on religious grounds. Before the bloody skirmishes of 1888-1892 (the religious wars in Buganda), Christianity had already taken a bloody turn when the first African converts were killed by Mwanga the King of Buganda Kingdom. Mwanga, through his chiefs had asked the African Christian converts to repudiate their new faith or face execution by fire. Majority of the converts, who included mainly court pages, disobeyed the King. In my opinion, the response to the king's threats of death depended on the victims' appropriation of scriptures especially as they read various biblical stories into their life situations. Those who read their situation in the context of biblical Daniel thought that God will intervene in their situations as he intervened to save Daniel (from lions), and Meshach, Shedrack and Abednego (from Nebuchadnezzar's furnace) in Daniel 3:17. While those who interpreted their situation in light of the events in the Acts of the Apostles, were convinced of the heavenly paradise like Stephen in Acts 7. In fact, Matthias Kalemba, one of the people burnt by Mwanga is recorded to have said to Luke Banabakintu, a fellow martyr, "Goodbye my friend we shall meet again in heaven."

In the contemporary contexts, earlier African leaders like Jomo Kenyatta used the Bible in his anticolonial slogans in Kenya. In the modern times, there both the clergy and lay people have used the Bible as a point of reference to call their politicians to good governance: In Uganda, the late Bishop Luwum and others criticized Iddi Amin on the basis of the biblical theme of good leadership. In Kenya, Christian leaders from the Nyanza, Rift Valley and Western Provinces blamed the leadership of Mwai Kibaki for tolerating corruption in government. Quoting Proverbs 6:30-31, the church leaders wondered why Mr. Kibaki protects corrupt officials instead of bringing them to justice. This scenario can be understood as the oversight role of the clergy to use the Bible as their source of authority to condemn evils that affect their society. This practice is also common in the Bible

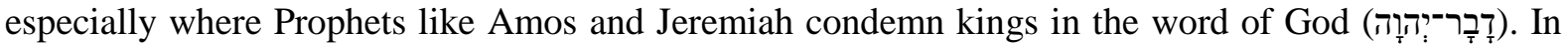
the New Testament John the Baptist attacked the mischief of Herod and Herodias (Mark 6:17-20).

In recent history, another African leader who evoked the Bible in his political speeches was Thabo Mbeki of South Africa. However, Mbeki seems to invoke the moral aura of the Bible in the seemingly unique context of South Africa. In his Bible appropriations as well analyzed by Gerald 
West, Mbeki is dealing with questions of racism, ubuntu, national unity and development, which the republic of South Africa urgently needed after the apartheid era. Outside Africa, there are renowned politicians who, in their political capacities have quoted the Bible: David Cameroon, the Prime minister of Britain quoted from the Gospel of John in his 2012 Christmas message, apparently to give his message an appropriate Christian religious tone. Another incidence where the UK premier made reference to the Bible is in his King James Bible speech at the celebration of 400 years of the King James Bible. In Australia, the Prime Minister Kevin Rudd made theological comments on the Bible in relation to same-sex marriages and the Bible's role in slavery. Barack Obama, the US president has on several occasions quoted the Bible. For example, at the interfaith vigil in Newtown Connecticut, the president began his speech with seemingly a quotation from 2 Corinthians 4:16-18, that: "Scripture tells us, do not lose heart." He added that "though outwardly we are wasting away, inwardly we are being renewed day by day. For light and momentary troubles are achieving for us eternal glory that far outweigh them all." Obama on another occasion, while on the campaign trail addressed his supporters in 2012 at the University of Vermont in Burlington and quoted Genesis 4 in his speech about values of "my brother's keeper' in contrast to 'you're-on-your-own economics.' There are other several incidents where Obama has quoted the Bible in the recent times that include the national prayer breakfast (Luke 12:48), the Oklahoma Tornado consolation speech (Isaiah 32:2).

One can easily observe that, though these world leaders have quoted the Bible, their modes of appropriations are straight forward and contextually relevant: It was relevant for David Cameroon to quote the Bible in his Christmas speech, and it is also appropriate for Barack Obama to refer to the Bible at the Oklahoma sombre context that needed spiritual inspiration. Mr. Museveni on the contrary does not quote his Bible during moments that call for spiritual edification or consolation. There are no moments the president has visited bereaved communities with the Bible. In some cases he has visited such mourning scenes with his gun. Moreover it has been observed that Mr. Museveni does not go to Church or identify himself with any Christian denomination in the country. He is simply a politician, who is convinced that his Bible appropriation is the correct interpretation.

\section{Yoweri Museveni: The Political Character}

Mr. Museveni studied Economics and Political science from the University of Dar es Salaam (Tanzania) from 1967-70. He read the works of socialists like Fanon, Lenin, Marx, Rodney and Mao. While at Dar es Salaam University, he headed a students' association called University Students African Revolutionary Front (USARF), which was formed as a reaction against the rightist University Staff. USARF was closely identified with Mozambican Liberation Front (FRELIMO). In 1972, Museveni was the leader of the Front for National Salvation (FRONASA) fighters that fought alongside Milton Obote's Kikozi Maalum and Tanzanian forces to overthrow Dictator Iddi Amini Dada in 1978. Museveni in 1980 participated in the presidential election race in Uganda, which he lost to Milton Obote.

Museveni became the president of Uganda in 1986, after successfully leading an armed guerrilla rebellion against the Obote II government. In his first address to the nation in January 1986, Mr. Museveni said his change of government was a fundamental revolution, against "previous regimes, which had been sectarian and neocolonial, presiding over an economy which was not properly integrated."

I personally regard Mr. Museveni a very savvy politician Africa has ever had. As a student of Fanon, Lenin, Marx, Rodney and Mao, Museveni obviously ingested, and apparently digested the socialist ideals of captivating the will of the masses to legitimize a movement. For example, he learned that women in Uganda constitute the highest number of potential voters; and by integrating this part of the population into active political participation, he would not only gain legitimacy for his regime but would be assured of a sizable block-vote that would strengthen his political grip on Uganda Presidency. He named Specioza Wandira Kazibwe; a woman as his vice-president to engender his political agenda. This earned Museveni great political mileage from the women's electorate as many women regard Museveni as a pillar of hope for emancipation. But Museveni does not support or encourage feminist issues. His attitude towards women's issues in recent years clearly reflects that, Museveni still maintains the patriarchal strings that hold the African society. In 2005, his government banned the vagina monologues in the Ugandan capital Kampala, and between 2010 and 2013, he refused to sign into law the Domestic Relations Bill and Marriage and Divorce Bill, which were aimed at protecting women's rights. Sylvia Tamale may be right in her view that Museveni's government is fundamentally similar to previous regimes in showing commitment to women's issues. 
Revealingly, in his parabolic book "Sowing the Mustard Seed" President Yoweri Museveni has written a parable, which I have embellished in an aristocratic manner as follows:

A subject...did a distinguished service for the king. And the king asked his subject how he could reward him. He said to the king: ['My Lord the King, your] servant does not want any gift from you. All I want is that when we are in a public place, [may my Lord the King] call his subject by name...it will help me very much because if the king calls his servant by name in front of so many people, everybody will wonder who I am and they will all come to your subject and help him.'...this is what we did for the women.

Museveni's parable reveals tensions between democratic ideals of equality and sovereignty and patriarchal ideals where men as kings award and revoke positions of power and recognition to their subjects (women). It projects a wishful image of a docile subject, a woman, happy to be a servant so long as she is flattered with names and titles as Vice President, Honorable Member of Parliament, or Honorable Minister. The parable also reveals that upon being rewarded, the subject has to continue doing the "distinguished service for the king" or else the king will no longer recognize her by name in this public place - politics.

Mr. Museveni has a strong zest for power and skills to clinch his claws on it. He is very alert and watchful of the political climate in Uganda and beyond, and has in recent years cleverly molted and reinvented himself to suit the contemporary political seasons and dynamics within and outside the Ugandan borders. He has reinvented his political relevance in the East and Central African region through his activities in the creation of Rwanda and South Sudan, and the pacification progress of Somalia and the Democratic Republic of Congo. In response to the recent conflict in South Sudan, Museveni was very quick in dispatching the Ugandan armed forces under the pretext of preventing a potential genocide. His involvement in Somalia has been applauded by the United States on several occasions, which earns his political existence credibility as the political and military prefect in the Great Lakes Region.

Despite the mounting pressure from political opponents in the recent years Museveni has managed to stay on the helm of political power for so longtime. He knows how to manipulate traditional and religious sentiments of the electorate to his advantage. He relates well local languages to his political messages, which leaves his audience entranced. In 1996, he metaphorically carried a grinding stone locally called Olubengo to symbolize a person of authority, a parental figure bearing a burden of feeding the nation. This act infantilized the opposition in the view of excited Ugandans especially the rural populations who overwhelmingly voted for Museveni. In 2010 general elections, Museveni beat the imaginations of many of his opponents who had criticized his political potency on the basis of his age and stamina to lead Uganda beyond his 25years in power: Museveni composed and sung a rap song called "You want another rap!" which he launched at a pre-nomination rally in Kampala. This caused a lot of excitement throughout the country especially among the youths who constitute a significant voter population. The song seemed to have been composed from the Kinyakole royal poem, and was embedded with relevant political imageries for Mr. Museveni: the singer relates his humble beginning and accentuates the importance of a stick to the singer. The stick transforms the singer's life to a famous and powerful figure in his community. It is this stick he would use to defend his territory from invaders coming from Ngarama and opening (shaking) their mouths like Rutendegire (apparently a rival king or chief from Ngarama). The semiotics of this song relate with Museveni's humble beginning and the centrality of the gun and the military in Museveni's rise to power and government. The invaders in question allude to the political opposition in Uganda. Museveni's relationship with the opposition in the recent years reveals that he is determined to use his stick well to keep the invaders from his political space. Besides the army, the Uganda Police Force is highly militarized and headed by military officials. It has been ruthless in keeping law and order in the Museveni's political space. It is not surprising to always see the Ugandan president in a military uniform when on official duties within the country partly to remind Ugandans of his source of fame and power and also to suit the perception in Uganda that "military is equivalent to power and civilian equivalent to weakness."

\section{The Bible in Museveni's Political Rhetoric}

This article samples a few of his political speeches where biblical texts have been used. The analysis of the president's parabolic statements is done within the framework of nationalism, Panafricanism, 
social economic transformation and democracy, which are hallmarks of Yoweri Museveni's political agenda.

In 1997, while addressing the parliament of South Africa, Museveni said:

"May I urge you to use South Africa's unique position to engage in partnership with the rest of Africa in the form of investment, trade and tourism...I know that the Bible promises us that there will come a time when the lamb will lie in the bosom of the lion. However, that is all in the kingdom of heaven. Here on earth, lions still eat lambs."

The president apparently quoted from the eschatological passages of Isaiah 11:7 and 65:25, urging South Africa to engage in economic partnership with Uganda and the rest of Africa. Worth asking is: what unique position does South Africa have in relation to the rest of the continent, and what makes the South African context unique? Obviously, the socio-economic infrastructure which the apartheid era left like industries, roads, financial institutions, human and financial capital, education and technological institutions make South Africa unique from the rest of Sub-Saharan Africa. However, the People of South Africa, Museveni suggests, should not be complacent with the victory over apartheid gains. The end of apartheid in South Africa should translate to the socio-economic transformation of the entire African continent. To Museveni, the end of apartheid does not herald the biblical time when lambs shall lie in the bosoms of lions. South Africans are still on earth and victims of the inescapable Lions, which are the agonizing forces of Western Imperialism, poverty, unemployment exploitation, ignorance and diseases, which dehumanize people on the African continent. In Africa poverty still looms at large. South Africa is in the geographical context of the rest of Africa and South Africans are therefore Africans who should join hands with the rest of the continent in the struggle to attain sustainable levels of economic growth and development, and improving the dignity of African people. Museveni infers that poverty, technological backwardness, disease and infrastructural problems in the rest of Africa constituted a challenge to South Africa in various ways like trade, investment and tourism. Engaging in partnership with the rest of the continent would constitute a symbiotic relationship rather than parasitic. South Africans will deal with several monstrous lions like poverty, economic stagnation, refugee problems and many others when it embraces the panafricanist's dream of economic partnership with the rest of the continent.

At the $68^{\text {th }}$ United Nations Assembly (25 $5^{\text {th }}$ September 2013), President Museveni mentioned two important points: The Millennium Development Goals (MDGs) in Africa and the Challenges of global partnership for Africa. In the first case, Museveni elaborated on the various bottlenecks that affected African countries in the realization of MDGs. He however scored the performance of his government tremendously in key areas of the MDGs like eradication of poverty, gender equality, reduced child mortality etc. in Uganda. Interestingly, before he could go on to his next topic (challenges of global partnership for Africa), Museveni interrupted his speech with two Bible quotations from Matthew 7:16-20 that: "By their fruit you will recognize them. Do people pick grapes from thorn bushes, or figs from thistles? Likewise, every good tree bears good fruit, but a bad tree bears bad fruit. A good tree cannot bear bad fruit, and a bad tree cannot bear good fruit. QEvery tree that does not bear good fruit is cut down and thrown into the fire. Thus, by their fruit you will recognize them;" and Matthew 5:16 "in the same way, let your light shine before others, that they may see your good deeds and glorify your Father in heaven". And added that: "A good system will prove its superiority by example." These verses were counter referenced with 1 Corinthians 10:31 and Philippians 1:11.

This interruption was followed by his next topic on the challenges of global partnership on the African continent. Museveni intimated what he called "our anger" against the arrogance of the International Criminal Court (ICC) in relation to the elected leaders of Kenya. To Museveni, the ICC was mishandling the "complex African Issues." He demanded that African problems be left for Africans to handle. The current President of Kenya Mr. Uhuru Kenyatta and his deputy Mr. William Ruto were facing trials at the ICC in relation to the post election violence that took place in Kenya between December 2007 and February 2008.

The literary structure of Museveni's speech is that the biblical quotations are sandwiched between two aspects, which cannot be attributed to mere chance or accident. The parabolic rendition of these Bible verses seems to serve two different purposes: On one hand as a smart conclusive remark for Museveni's 'good tree-good fruit' governance, and on the other hand, an appropriate preamble to the ICC's "arrogance" and indulgence in the "complex African issues." Museveni infers that his 
government, as the 'good tree,' 'good system' has produced good fruits in relation to the MDGs. He suggests that his light shines before others, and his government should be appreciated in that light. His government proves its superiority through its performance. Conversely, the ICC, which is tagged arrogant, is the bad tree, and its involvement in Kenyan Politics will produce bad fruits. Kenya lies on the Eastern border with Uganda, and the two countries enjoy good socio-economic and political relations. Kenya is a key player in the East African Community, and President Uhuru Kenyatta is a very important ally of Museveni in his campaign for the political unification of East African States. Museveni seems right in worrying that the ICC indictments of Kenya's top politicians would disrupt the regime. Kenyan leaders would spend valuable time in The Hague court answering criminal charges, and it was feared that if found guilty, they would be imprisoned, hence cause a political crisis in the key member state of the East African community. The likely political crisis can have adverse socio-economic and political consequences for Uganda. Uganda being a landlocked country, conducts her international trade mainly through the Kenyan Port of Mombasa. Political skirmishes in Kenya in recent years caused serious economic hardships in Uganda especially due to shortage of essentials like petroleum. ICC, as Museveni infers, is the bad tree that should be cut off from Africa, and African problems be left for Africans to handle. The ICC, which is housed at Hague in the Netherlands, is perceived as a foreign court with neo-imperialistic tentacles against African leaders. Worth noting is that Museveni's demand for African problems to be left for Africans to handle, resonate with Marcus Garvey's $20^{\text {th }}$ Century rhetoric of Africa for Africans.

In 2012, the rotten underbelly of corruption was exposed in various top government organs in Uganda associated with wide scale swindling of donor funds in the Prime Minister's office, Ministry of Health and Ministry of Public service. This resulted in the withdrawal of donor aid to Uganda by UK, Ireland, Austria and other EU countries. Critics to the Museveni government projected poor economic performance and service delivery, and the resultant fall of the Museveni's regime as the result of aid cuts to Uganda. However, in his budget report of 2013, Mr. Museveni gave the nation a reassurance, and quoting the appropriate Bible verse said:

... those partners who cut off aid because we had discovered the corruption were not correct...In spite of this "aid cuts" and other global economic problems, our economy grew by $5.1 \%$, inflation was brought to $3.6 \%$ and the reserves stand at US $\$ 3.3$ billion. This proves what the Bible says - what comes from outside the body cannot kill the body or do irreparable harm; it is what comes from inside the body that causes irreparable damage. It is our internal weaknesses that need to be addressed. This is in the Book of: Mark Chapter 7 Verse 15: "Nothing that goes into a person from the outside can make him unclean. It's what comes out of a person that makes a person unclean".

In the above proverbial statement, Museveni infers that his government is a body system. What kills the body system is that which is internal but not foreign. To Museveni foreign aid cuts cannot kill his government or the economy. Though he accepts that corruption is an internal problem and weakness in his NRM government, it should be consciously and carefully dealt with in order not to hurt the body-system. Metaphorically, decisive action against corruption in his government is carrying out an open surgery on a body without safety precautions that can result into the death of the body. To keep the political gestalt of his regime, it can be stated, Museveni went slow on corruption for so long. It is not a secret that Museveni on some occasions thought corruption is good, and defended his closest, loyal and trusted political aides who were implicated in corruption. For instance Salim Saleh, Amama Mbabazi, and other influential ministers. It is reasonably clear that Mr. Museveni did not want to spoil relations with his loyal lieutenants like Amama Mbabazi who had on several occasions proven politically influential and strong cadres in helping Museveni consolidate political power. Incriminating these 'corrupt officials' would be equivalent to carelessly hitting a fly that is perching on his scrotum or daring an open surgery that would dysfunction an essential body organ with the consequent likelihood of killing the body - the government.

On $23^{\text {rd }}$ November 2012, at the $16^{\text {th }}$ COMESA summit President Museveni rightly observed that the greatest disadvantage Africa faced at independence was political balkanization of this continent. That, whereas other continents have got fewer countries Africa has got 54 countries. He noted that this balkanization affected Africa's political and economic cohesion and advancement. Museveni observed that Africa needs to widen her market base - through regional corporations like the East African Community (EAC), ECOWAS, COMESA and SADC in order for "us to negotiate with 
others (USA, EU, China, Russia, India, South America, Japan, ASEAN, etc) for access to their markets." At this point, the president brought in the Bible text from Luke 8:18: '...For whoever has, more will be given to him; and whoever does not have, even what he thinks he has will be taken away from him..."”

The significance of Museveni's Bible quotation in this case is that it reiterates the bountifulness of Africa's riches in terms of her people and her natural resources. African natural resources include petroleum (oil), minerals (gold, diamonds, silver, iron, copper, uranium, cobalt, and many others), and agricultural goods (coffee, cocoa, fruits) and tropical forests. However, as a Swahili proverb goes, "Unity is strength, division is weakness" the riches or Africa shall always go to waste unless Africans deconstruct the colonial political and economic designs and reorganize Africa along a united political and economic system. Museveni infers that political and economic unity of African countries will enhance Africa's production and export capabilities in the global economic niche. Africa needs a broader market base, easy mobility of labor and capital and free movement of goods and services. The current political and economic systems are restrictive in the realization of sustainable growth due to restrictions associated with cross-border systems and trade tariffs that exist between many African countries. In essence, African economies shall remain weak, without anything to offer on the global stage. Africa shall remain susceptible to exploitation and eventual depletion of natural resources and brain drainage of her human resource by the developed countries. Indeed, majority of African countries are heavily entrenched in the exploitation of natural resources which are exploited in their crude form and patented by Western manufacturing companies. For example Option Biotech, a German company has patented Aframomum stipulatum the Congolese seed plant from which Bioviagra, anti-impotence drug is manufactured. The same applies to Tanzania's Impatiens usambarensis, which is patented by the Swiss's Sygenta in the manufacturing of hanging basket plant. This example illustrates Museveni's proverbial Bible rendition that what Africa thinks she has is being taken away by those who have. Revealingly, Melvyn Davies of SR Pharma (UK) that patents Uganda's mycobacterium said: "If you pick up a natural substance from the street, does that mean it belongs to the country in which you found it?...The issue is not about where the source was but the work that has been done to develop it. Should Uganda share in the profits that will be generated if [it did not invest in the development] Melvyn's view resonates with Museveni's fears that in the absence of unity, Africa is a no-place, and will continue to lose her resources to the West. African political and economic unity is urgently needed to streamline the flow of such valuable resources or demand for a reasonable share of profits made by these companies, ease mobility of labour, capital, scientific knowledge and skills, and build confidence of her own human resource and enhance Africa's competitiveness in the international community.

As the African saying goes - charity begins at home, Museveni's political ideas and legitimacy should be examined from his Ugandan context. Though he claims to have brought into Uganda democracy and freedom as personified in his Mustard seed, in recent years, the Museveni government has been criticized on several grounds of human rights that range from media restriction and closure of media houses to intolerance to political opposition. Maria Nzomo, Professor at the Institute of Diplomacy and International studies (University of Nairobi) recommends that the Museveni government in Uganda, other issues should guarantee freedom of assembly and expression. It is evident that Museveni does not tolerate people of different political opinion from his. Several of his cadres who differed with his opinions have been removed from government. A case in point is Miria Matembe, a Ugandan female politician, who upon challenging her leader on matters of political propriety was sacked from cabinet, demonized and politically isolated. Matembe wanted Museveni to leave power after serving the country for so long in order to set precedence for political stability. This is the time when Mr. Museveni was lobbying Members of Parliament to amend the constitution to remove term limits for the presidency in Uganda.

It therefore turns out that contrary to the biblical Mustard tree, which is all inclusive; the Mustard seed (tree) in Museveni's political kingdom is exclusive. He is the planter of the seed and he is the bird as well - the arch-bird that perches on his tree. He determines the rules for admission and dismissal from his tree. He does not tolerate any bird that will sing an irritating song near him. Women, as discussed above are welcomed to this kingdom, and called by names and salutations in this public space only if they obey the rules of the game. It is reasonable therefore, to state that Museveni who utters biblical verses is not the Museveni of the biblical character - the messianic figure. However, "no matter how 
one hates a dog, one cannot say that it has black teeth;" in the context of panafricanism, Museveni has been a great leader Africa has ever had. Credit should be given for his role in rewriting the history of Uganda, the once war torn country.

That African problems need to be solved by Africans is reminiscent of the twentieth Century panafricanist ideas like Marcus Garvey and Malcolm X. In his resentment against the activities of the ICC in Kenya and the aid-cut in Uganda due to corruption, Museveni seems to believe in dealing with African complex issues locally and nationally to preserve the integrity of the African systems. To Museveni, foreign intervention is an overture of neo-colonialism and western paternalism.

Museveni's didactic rendition of the Bible bears distinctly African flavor. They arise from a Christian environment, and if one further investigates they are political, though politics with a selfish goal, as indeed his utterances are selective and omits relevant African problems as human rights and political power succession. Probably one can also get an impression that Museveni is a down - to earth Christian and reader of the Bible, as indeed he does not quote any other spiritual authorities like the Quran. This is however debatable. As earlier mentioned the Ugandan president does not use the Bible in the conventional religious sense or known for going to Church. His rhetoric rendering of the Bible can be said to be one of his political insignias. Therefore, if Stein was to define for us the parable in Museveni's contexts, he would most likely say that it is a heavenly (biblical) story told with a political or earthly meaning.

\section{REFERENCES}

[1] For instance, there are comparative studies that legitimize African culture and religion; that use African contexts as resources for the interpretation of the Bible; that make the African context the explicit subject and focus of biblical interpretation, among others.

[2] Paul Gifford, African Christianity : Its Public Role (London: Hurst, 1998), 122.

[3] In the mid $20^{\text {th }}$ Century, African Nationalists like Jomo Kenyatta in Kenya significantly used the Bible in the anti-colonial slogans (See Jomo Kenyatta, Facing Mount Kenya (1938), 273.) to bolster their propaganda against colonial governments, who were considered as the 'other' or foreigners. The aim of these politicians was to capture power and become independent.

[4] Mbengu D. Nyiawung, "Contextualising Biblical Exegesis: What Is the African Biblical Hermeneutic Approach?," Theological Studies 69, no. 1 (2013), 3-4.

[5] Nyiawung, "Contextualising Biblical Exegesis", 4

[6] John Samuel Mbiti, Mbiti,. Bible and Theology in African Christianity. Oxford: Oxford University Press, 1986. 26-27.

[7] "Speech by H.E. Yoweri Kaguta Museveni President of the Republic of Uganda at the 16th Comesa Summit ", The State Hosue of Uganda [http://www.statehouse.go.ug/media/ speeches/ 2012/11/24/speech-he-yoweri-kaguta-museveni-president-republic-uganda-16th-comesa-sum (accessed 24th October 2013)].

[8] Yoweri Museveni, Elizabeth Kanyogonya, and Kevin Shillington, Sowing the Mustard Seed: The Struggle for Freedom and Democracy in Uganda(London: Macmillan, 1997), xiii.

[9] Museveni, Kanyogonya, and Shillington, Sowing the Mustard Seed, xiii.

[10] Hellen Mukiibi; Henry Mukasa; A Sengendo; Moses Walubiri, "Museveni Sets Eyes on a First World Uganda by 2062," The New Vision Online [http://www.newvision.co.ug/news/635594Museveni-sets-eyes-on-a-first-world-Uganda-by-2062.html] (Accessed 24th October (2013). See also Museveni, Kanyogonya, and Shillington, 217.

[11] Robert H. Stein, An Introduction to the Parables of Jesus (Philadelphia: Westminster Press, 1981), 15 and 27.

[12] John MacDougall, The Old Testament Parables (London: Clarke), 9.

[13] Uganda-Bureau-of-Statistics, 2002 Uganda Population and Housing Census (Kampala: Republic of Uganda, 2002)

[14] Aloo Osotsi Mojola, "The Swahili Bible in East Africa from 1844 to 1996: A Brief Survey with Special Reference to Tanzania," in The Bible in Africa : Transactions, Trajectories, and Trends, ed. Gerald O. West and Musa W. Dube Shomanah (Leiden: Brill, 2000), 511-514.; Aloo Osotsi Mojola, "100 Years of the Luganda Bible (1896-1996)," in The Bible in Africa : Transactions, Trajectories, and Trends, ed. Gerald O. West and Musa W. Dube Shomanah (Leiden: Brill, 2000), 525-526. 
[15] Gerald West, "A Real Presence, Subsumed by Others: The Bible in Colonial and Postcolonial Contexts," Semeia 88, no. (2001), 199.

[16] Husein Bogere, "Bible a Forgery, Says Col. Gadaffi," Monitor Online (March 20, 2008) (2008). [http://www.monitor.co.ug/artman/publish/news/Bible_a_forgery_says_Col_Gadaffi_62350.sht $\mathrm{ml}$ (accessed 1st June 2009).]

[17] Husein Bogere and Jane Nafula, "Gadaffi Remarks Anger Christians," Monitor Online (March 21,2008)(2008).[http://www.monitor.co.ug/artman/publish/news/Gadaffiremarksanger Christians 62401.shtml> (accessed 1st June 2009).]

[18] J. Faupel, 177; Quoted in Adrian Hastings, Hastings, 379. Emphasis mine

[19] "Opened Pastoral Letter to H.E. Hon. Kofi Annan Head of the Au Mediation Team, from Bishops and Church Leaders from Nyanza, Western and Rift Valley Provinces.", [http://afri canpress.wordpress.com/2008/01/30/opened-pastoral-letter-to-he-hon-kofi-annan-head-of-theau-mediation-team-from-bishops-and-church-leaders-from-nyanza-western-and-rift-valleyprovinces/ (accessed 1st June 2009).]

[20] Gerald O. West, "Thabo Mbeki's Bible: The Role of the Religion in the South African Public Realm after Liberation," Bulletin for Old Testament Studies in Africa (2008). [http://www.mhs. no/aotp?72 (accessed 10th February 2014).]

[21] "David Cameron Quotes Bible in Christmas Message", BBC [http://www.bbc.co.uk/news/uk20835186 (accessed 30th October 2013).]

[22] "Prime Minister's King James Bible Speech", UK Government [https://www.gov.uk/ governm ent/news/prime-ministers-king-james-bible-speech (accessed 30th October 2013).]

[23] Rick Morton, "Scripture Is Simply All Greek to Rudd", The Australian [http://www. Theaustralian.com.au/national-affairs/election-2013/scripture-is-simply-all-greek-to-rudd/story-fn9qr68y1226710083911\# (accessed 30th October 2013).]

[24] Jake Tapper; Matthew Larotonda,"Connecticut School Shooting: Obama Says Nation Faces 'Some Hard Questions'", ABC News [http://abcnews.go.com/Politics/connecticut-school-shoo ting-obama-nation-faces-hard-questions/story?id=17993361 (accessed 30th October 2013).] Also, "Obama Speech at Newtown, Ct Memorial Service (Abc News) 12-16-2012", [http://www. youtube.com/watch?v=Y4W7TJx1p8M (accessed 30th October 2013).]

[25] Terence P Jeffrey, "Obama Calls for More Redistribution of Wealth, Declaring: 'I Am My Brother's Keeper'", [CNSNews http://cnsnews.com/news/article/obama-calls-more-redistribution -wealth-declaring-i-am-my-brother-s-keeper (accessed 30th October 2013).]

[26] Anugrah Kumar, "Obama Quotes the Bible to Urge Americans to 'Step up' Aid to Oklahoma Tornado Survivors" [http://www.christianpost.com/news/obama-quotes-bible-to-urge-americansto-step-up-aid-to-oklahoma-tornado-survivors-96698/ (accessed 30th October 2013).]

[27] Charles Onyango-Obbo, "The Bududa Killer Floods Are Just a Mirror of Uganda's Politics", The Monitor Publications [http://www.monitor.co.ug/OpEd/OpEdColumnists/CharlesOnyango Obbo/ Bududa-killer-floods-are-just-a-mirror-of-Uganda-s-politics/-/878504/1436100/axb5nwz/ind ex.html (accessed 30th October 2013).]

[28] Gifford, 122.

[29] Edison Akugizibwe, "Museveni: Bible Misinterpreted on Wealth Creation" [http://chimpreports .com/index.php/mobile/news/10609-museveni-bible-misinterpreted-on-wealth-creation.html (accessed 22nd October 2013).] Citing the example of Genesis 1:28, Museveni discouraged the literally textual meaning of the verse and twisted it suit his contextual and contemporary issues in his political theatre. Museveni called upon that Christians to use their numerical strength to transform the socio-economic antecedents not only quantitatively but more so qualitatively. To Museveni, subduing the earth alluded to in Genesis 1:28 is not numerical multiplication of the human race but harnessing nature for socio-economic transformation.

[30] Government of Uganda, "State House: The Republic of Uganda" [http://www. statehouse.go.ug/ president.php?category=The\%20President (accessed 17th. January 2009).]

[31] Museveni, Kanyogonya, and Shillington, 172.

[32] See Aili Mari Tripp, "The Politics of Autonomy and Cooptation in Africa: The Case of the Ugandan Women's Movement," The Journal of Modern African Studies 39, no. 1 (2001), 113 114. 
[33] Women of Uganda Network, "Response to President Yoweri Museveni's Views on the Reform of the Domestic Relations Bill by Hon. Sheila Kawamara Mishambi, Member, East African Legislative Assembly April 17, 2003 " [http://www.wougnet.org/Alerts/drbresponseSKM.html (accessed 20th January 2009).]

[34] Sylvia Tamale, When Hens Begin to Crow: Gender and Parliamentary Politics in Uganda (Boulder, Colo.: Westview Press, 1999), 20.

[35] Museveni, Kanyogonya, and Shillington, 191-192.

[36] Frederic Musisi, "UPDF Came to Prevent a Genocide," (2014). [http://www.monitor.co.ug /News/National/UPDF-came-to-prevent-a-genocide---S--Sudan/-/688334/2139294/-/item/0//m9x2de/-/index.html (accessed 9th January 2014).]

[37] USA-News, "Africom Chief Applauds Uganda's Role in Somalia", Embassy of the United States [http://kampala.usembassy.gov/africom_chief_applauds_uganda.html(accessed 9th January 2014).]

[38] "Yoweri Museveni's Rap", [http://www.youtube.com/watch?v=XXe3uRL3gog (accessed 24th October 2013).]

[39] Jude Kagoro, "Why Museveni Loves His Army Uniform and Besigye Copies Him," (2012). [http://www.independent.co.ug/column/opinion/5583-why-museveni-loves-his-army-uniformand-besigye-copies-him-part-i (accessed 9th January 2014).]

[40] "Address by H.E. Yoweri Kaguta Museveni, President of the Republic of Uganda, to the Republic of South Africa's Parliament, Cape Town, 27 May 1997," Republic of South African parliament (South African Government information, 1997).

[41] Imperialism is perceived to be an inescapable phenomenon. Western Nations are believed to be in a binomial relationship with nations of Africa, Asia and Latin America; a relationship that is characterized by subordination to Europe and North America, economic and human exploitation and general inequality.

[42] "Statement by H.E. Yoweri Kaguta Museveni President of the Republic of Uganda at the 68th United Nations General Assembly", The State House of Uganda [http://www.statehouse.go.ug/ media/speeches/2013/09/25/statement-he-yoweri-kaguta-museveni-president-republic-uganda68th-united- (accessed 24th October 2013).]

[43] "Statement by H.E. Yoweri Kaguta Museveni President of the Republic of Uganda at the 68th United Nations General Assembly"

[44] "Presidential Budget Speech 2013", The State House of Uganda [http://www.statehouse.go.ug /media/speeches/2013/06/13/presidential-budget-speech-2013 (accessed 24th October 2013).]

[45] Edward Sekiika, "Corruption Can Be Good--Museveni," The Observer (2010). [http://www. observer.ug/index.php?option=com_content\&task=view\&id=8757\&Itemid=59 (accessed 11th January 2014).]

[46] Alex B Atuhaire and Simon Kasyate, "Uganda: Museveni Defends Gen. Saleh on Graft," The Monitor (2005). [http://allafrica.com/stories/200510280695.html (accessed 11th January 2014).]

[47] Edris Kiggundu and Hussein Bogere, "From 'Super' to Prime Minister," The observer (2011). [http://www.observer.ug/index.php?option=com_content\&view=article\&id=13584\&catid=78\&It emid=116 (accessed 11th January 2014).]

[48] Newvision, "I did not authorize any payments to Basajja - Museveni," The New Vision (2011). [http://www.newvision.co.ug/news/315022-i-did-not-authorize-any-payments-to-basajjamuseveni.html (accessed 11th January 2014).]

[49] "Speech by H.E. Yoweri Kaguta Museveni President of the Republic of Uganda at the 16th Comesa Summit".

[50] Andrew Buncombe, "African Bio-Resources," The Independent (2006). [http://www. Independent.co.uk/news/world/politics/african-bioresources-exploited-by-west-466824.html(accessed 18th January 2014).]

[51] Andrew Buncombe, "African Bio-Resources,"

[52] Maria Nzomo, "An Analysis of Human Rights Issues in Uganda: Case Study of East and Horn of Africa Human Rights Defendes Project (Ehahrdp) Uganda", University of Nairobi [http://idis. uonbi.ac.ke/node/370 (accessed 8th January 2014 2014).]

[53] This is based on the interviews I conducted with Mrs Miria Matembe on the $16^{\text {th }}$ October 2012 at her home in Kampala, the capital of Uganda. 


\section{AUTHOR'S BIOGRAPHY}

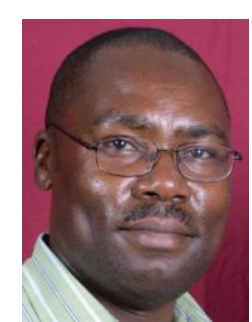

Robert Kuloba Wabyanga, lives and teaches Old Testament studies in Kyambogo University in Uganda. His focus is on bible hermeneutics and the history and interpretations of the Bible in African context. Special emphasis is on the fusion between the Bible and African ideologies that birthed the post-colonial African hybrid context. 